\title{
Hubungan antara Nilai Indeks Pertumbuhan Vertikal Wajah dan Kejadian Otitis Media Kronik pada Subras Deutero Melayu Dewasa
}

\author{
Henny Widyastuti, ${ }^{1}$ Nur Akbar Aroeman, ${ }^{2}$ Wijana $^{2}$ \\ ${ }^{1}$ UPTD Rumah Sakit Umum Daerah Lembang, ${ }^{2}$ Departemen Ilmu Kesehatan Telinga Hidung \\ Tenggorokan (THT)-KL Fakultas Kedokteran Universitas Padjadjaran \\ Rumah Sakit Dr. Hasan Sadikin Bandung
}

\begin{abstract}
Abstrak
Nilai indeks pertumbuhan vertikal wajah (VERT) menggambarkan pertumbuhan kraniofasial. Nilai ini berdampak pada pertumbuhan tuba eustakius. Perbedaan morfologi kraniofasial berkorelasi dengan fungsi dan anatomi tuba eustakius serta otot tensor veli palatini yang berperan pada patogenesis otitis media kronik (OMK). Telah dilakukan penelitian yang bertujuan untuk mengetahui pengaruh nilai indeks pertumbuhan vertikal wajah (VERT) dan sefalometri terhadap kejadian OMK yang merupakan penelitian kasus-kontrol dengan subjek yang berobat jalan di poliklinik Telinga Hidung Tenggorok-Bedah Kepala Leher (THT-KL) Rumah Sakit Dr. Hasan Sadikin Bandung selama bulan September-November 2013. Dilakukan pengukuran sefalometri dua kelompok, yaitu kelompok penderita OMK dan kontrol, perbedaan nilai rata-rata keduanya dihitung dengan uji-t atau Uji Mann-Whitney, kemudian dihitung indeks VERT rata-rata, dan hubungan antara kedua variabel dianalisis dengan Rasio Odds. Terdapat 4 dari 7 subjek kelompok kasus merupakan tipe wajah bulat pendek/brakifasial dengan sudut kedalaman wajah lebih besar $(\mathrm{t}=3,408 ; \mathrm{p}=0,005)$ dan sudut bidang mandibula lebih kecil $(\mathrm{t}=-4,055 ; \mathrm{p}=0,002)$. Subjek dengan indeks VERT $>+0,5$ (brakifasial) memiliki risiko 8x untuk menjadi OMK (OR: 8; IK 95\%: 0,41-309,1). Simpulan, indeks VERT berhubungan dengan kejadian OMK pada subras Deutero Melayu dewasa. [MKB. 2014;46(3):168-77]
\end{abstract}

Kata kunci: Indeks vertikal, otitis media kronik, sefalometri

\section{Association between Vertical Growth Index and Chronic Otitis Media Incident in Adult Deutero Malays}

\begin{abstract}
Vertical growth index (VERT) describes craniofacial growth. This value affects the eustachian tube growth. Differences in craniofacial morphology correlates with eustachian tube anatomy function and tensor veli palatini muscles that play a role in the pathogenesis of chronic otitis media (COM). This study aimed to determine the effect of vertical growth index (VERT) and cephalometry on COM incident. The design was case-control with subjects from the outpatient clinic of otolaryngology head and neck surgery, Dr. Hasan Sadikin General Hospital during the period of September to November 2013. Subjects were divided into two groups: COM group and control group. Cephalometric measurements were performed and the mean values difference of both groups were calculated using $\mathrm{t}$ test or Mann-Whitney test. The mean index VERT was then calculated for each groups and relationship between risk factors and effects were analyzed using Odds Ratio. Four of 7 subjects in the COM group have a short round face/brachifacial type with greater facial depth angle $(t=3.408, p=0.005)$ with smaller mandibular plane angle are $(\mathrm{t}=-4.055, \mathrm{p}=0.002)$. Subjects with VERT index $>+0.5$ (brachyfacial type) have eight times higher risk to be COM (OR: 8; 95\% CI: 0.41 to 309.1). In conclusion, the VERT index has an association with COM incident in adult Deutero Malays. [MKB. 2014;46(3):168-77]
\end{abstract}

Key words: Cephalometry, chronic otitis media, vertical index

Korespondensi: Henny Widyastuti, dr., Sp.THT-KL, UPTD Rumah Sakit Umum Daerah Lembang, Jalan Raya Lembang KM 11,4, Desa Gudang Kahuripan, Kabupaten Bandung, mobile 081322164057, e-mail hw thtk1@yahoo.com 


\section{Pendahuluan}

Otitis media kronik (OMK) merupakan sebuah fenomena yang masih menjadi masalah kesehatan masyarakat, terutama pada anak dan dewasa di Afrika, Asia, serta Amerika Latin. ${ }^{1}$ Otitis media kronik adalah proses infeksi kronik mukosa telinga tengah, mastoid, dan apeks petrosa yang ditandai dengan keluarnya cairan dari telinga tengah lebih dari tiga bulan melalui membran timpani yang perforasi persisten.

Bentuk basis tengkorak dan proses pergeseran dari rahang atas selama pertumbuhan kraniofasial sangat berkorelasi dengan pertumbuhan tuba eustakius. $^{2}$ Proses deviasi yang terjadi selama perkembangan kraniofasial sering berdampak pada OMK dan berdampak pada prognosis OMK di masa dewasa selanjutnya. ${ }^{2}$

Pautow melaporkan bahwa morfologi tuba eustakius berhubungan dengan bentuk wajah/ kepala. ${ }^{3}$ Individu dewasa yang bentuk wajahnya brakifasial (bulat pendek) cenderung memiliki tuba eustakius yang pendek dan menderita otitis media, keadaan ini didukung oleh penelitian sebelumnya.

Tuba eustakius memiliki fungsi sebagai katup pengendali tekanan udara (pressure regulator) pada rongga telinga tengah, secara fisiologis berfungsi sebagai ventilasi, proteksi, dan juga clearance. ${ }^{4}$ Otot peritubal terutama tensor veli palatini secara aktif akan mendilatasi tuba untuk memperoleh transfer gas yang adekuat ke rongga telinga tengah. Tekanan negatif persisten pada rongga telinga tengah akibat disfungsi kronik tuba eustakius karena proses inflamasi akan menyebabkan transudasi cairan dari mukosa dan ruang interstitium ke dalam rongga telinga tengah (hydrops ex vacuo) yang meningkatkan proses inflamasi dan berdampak pada otitis media akut rekuren yang akan berkembang menjadi OMK. ${ }^{4}$ Seluruh suku yang mendiami kepulauan Indonesia dikelompokkan ke dalam Oriental berdasarkan klasifikasi Webster kamus dunia baru, dan menurut Enlow, fitur wajah oriental cenderung brakifasial (bulat, pendek). ${ }^{5}$ Fitur wajah seperti ini memiliki kesamaan dengan fitur wajah ras etnis Eskimo dan ras Indian, Amerika Utara yang memiliki prevalensi OMK yang tinggi. ${ }^{6}$

Brakifasial dikenal sebagai sindrom kepala datar (flat head syndrome) yaitu bentuk wajah/ kepala yang bulat pendek yang merupakan variasi bentuk kepala yang dihasilkan oleh fusi prematur sutura koronal pada kranial (kraniosinostosis). ${ }^{7}$ Berdasarkan hukum Virchow, kraniosinostosis akan mengubah pola pertumbuhan tengkorak sehingga menjadi tidak dapat berkembang secara perpendiculair (tegak lurus) terhadap fusi sutura tersebut dan dapat mengompensasi dengan tumbuh lebih banyak pada arah yang sejajar dengan sutura yang menutup tersebut sehingga mengakibatkan pembatasan pertumbuhan kepala anak itu ke arah depan dan ke arah belakang. ${ }^{7}$ Beberapa penyebab potensial penutupan prematur sutura yang telah diidentifikasi, adalah mutasi genetik dari gen FGFR 1, -2, -3, gen TWIST dan MSX2, pada kraniosinostosis sindromik, ${ }^{7}$ sedangkan penyebab kraniosinostosis nonsindromik masih belum diketahui, kemungkinan besar oleh faktor lingkungan seperti paparan ibu hamil terhadap rokok dan obat-obatan yang mengandung amina, ibu hamil dengan resistensi terhadap vitamin D karena gagal ginjal kronik, hipofosfatemia, obatobat teratogen seperti fenitoin, retinoid, valproat, aminopterin, metotreksat, flukonazol, dan juga siklofosfamid, faktor hormonal seperti hipertiroid dan penyebab faktor biomekanik yaitu tekanan pada kepala janin (fetal head constraint) selama kehamilan. $^{7}$

Kemaloglu dkk. menyatakan bahwa disfungsi tuba eustakius memiliki hubungan dengan proses tumbuh kembang kraniofasial sesudah lahir. Dalam penelitiannya, dilaporkan bahwa total panjang dasar tengkorak, tinggi wajah posterior atas, dan kedalaman maksila mempunyai efek yang menentukan pada dimensi panjang tuba eustakius, dan disimpulkan bahwa perkembangan tuba eustakius berkorelasi dengan perkembangan basis kranial dan kompleks nasomaksilaris. ${ }^{3}$ Oleh karena itu, setiap penghentian atau kelainan di daerah kerangka kraniofasial akan menyebabkan ketidakseimbangan pada tuba eustakius, yang dapat menyebabkan rentan terhadap otitis media. ${ }^{3}$ Menurut teori berpasangan, panjang basis kranial anterior menentukan ukuran panjang maksila dan mandibula. ${ }^{8}$ Pada fitur wajah brakifasial sudut basis kranial berada pada posisi lebih tegak sehingga membentuk kelengkungan (flexure) yang lebih besar ini mengakibatkan menurunnya dimensi anteroposterior dari fosa kranial anterior dan media, sehingga menyebabkan perpindahan maksila ke arah bagian posterior (retrusi maksila) dan pertumbuhan yang pendek dari kompleks nasomaksilari pada arah anteroposterior, dan kompensasimandibula berpindah ke bagian depan, sehingga menghasilkan profil yang cenderung prognatik. ${ }^{8}$ Selanjutnya, perkembangan maksila yang kurang akan menyebabkan pertumbuhan tuba eustakius dan juga otot-otot paratubal yang pendek. ${ }^{8}$ Dimensi palatum lunak yang pendek akibat perkembangan maksila yang kurang akan berdampak pada keterbatasan gerak muskulus tensor veli palatini pada proses pembukaan tuba eustakius, sehingga menyebabkan disfungsi tuba eustakius, yang akan rentan terhadap OMK. ${ }^{8}$

Menurut Ricketts dkk. analisis sefalometri OMK ditentukan dari pengukuran parameter linier 
dan sudut-sudut kraniofasial yang menentukan tipologi fasial.

Indeks pertumbuhan vertikal wajah (VERT) ditentukan melalui nilai aritmetika rata-rata dari perbedaan besar sudut kraniofasial subyek dengan nilai normal pada umumnya. ${ }^{3}$ Nilai indeks VERT dihitung dengan rumus:

$$
\begin{aligned}
\text { VERT }= & (\text { FA-nv/3 })+(\text { FD-nv/3 })+(n v-M P / 4)+(n v- \\
& \frac{\mathrm{AIFH} / 4)+(\text { ma-NV/4 })}{5}
\end{aligned}
$$

Keterangan:

nv $=$ nilai normal pada usia tertentu

$\mathrm{FA}=$ aksis wajah

$\mathrm{FD}=$ kedalaman wajah

$\mathrm{MP}=$ sudut mandibular plane

AIFH=tinggi wajah bagian bawah

$\mathrm{MA}=$ arkus/lengkung mandibula

Berdasarkan indeks VERT tersebut, subjek diklasifikasikan ke dalam 3 tipe bentuk wajah yaitu dolikofasial dengan indeks VERT kurang dari $-0,5$; mesofasial bila nilai indeks VERT berada di antara $-0,5$ dan $+0,5$; dan brakifasial bila indeks VERT lebih dari $+0,5{ }^{3}$

\section{Metode}

Penelitian ini adalah penelitian kasus-kontrol, hasil pengukuran parameter kraniofasial linier dan sudut yang sesuai dengan prediksi OMK kelompok kasus dan kontrol, lalu dihitung rataratanya. Dilakukan uji-t untuk distribusi normal atau Uji Mann-Whitney untuk distribusi tidak normal pada rata-rata kedua kelompok, perbedaan yang bermakna ditentukan dengan nilai $\mathrm{p}<0,05$ kemudian masing-masing subjek diklasifikasikan ke dalam tipe bentuk wajah apakah brakifasial atau nonbrakifasial berdasarkan indeks VERT dilakukan analisis tingkat kejadian OMK dengan faktor risiko indeks VERT $>+0,5$ menggunakan Rasio Odds.

Populasi penelitian adalah orang Indonesia subras Deutero Melayu (suku Aceh, Lampung, Jawa, Sunda, Bali, Menado, dan Minahasa ${ }^{9}$ ) yang dipilih dari dua generasi asli Deutero Melayu, yang datang berobat ke Poliklinik Telinga Hidung Tenggorok-Bedah Kepala Leher (THT-KL) RSUP Dr. Hasan Sadikin Bandung, usia dikategorikan ke dalam 3 kelompok; 20-29 tahun, 30-39 tahun, 40-49 tahun, subjek kasus didiagnosis menderita OMK dan dieksklusi apabila subjek mempunyai riwayat berupa alergi, pembesaran tonsil faringeal atau tonsila palatina, mempunyai cacat wajah seperti celah bibir, celah langit-langit, riwayat trauma atau pembedahan pada daerah wajah dan kepala. Sampel diambil secara consecutive sampling yaitu diambil secara berurutan selama bulan september sampai dengan bulan November 2013. Jumlah sampel yang dibutuhkan sebanyak 14 orang. Alat penelitian adalah otoskop Heine 3000 -Germany, nasoendoskopi kaku sudut $0^{0}$ (senda), tes kulit tusuk, mesin rontgen pesawat DR. Apelem Magnum kapasitas 300 mA 125 $\mathrm{KV}$, foto rontgen sefalogram lateral, foto schuller stenver, busur derajat, penggaris, spidol tracing, plastik transparan untuk tracing. Penelitian dimulai dengan mendapatkan inform consent dan anamnesis terhadap semua responden yang memenuhi kriteria inklusi, selanjutnya dilakukan pemeriksaan fisisTHT-KL yang meliputi otoskopi, nasoendoskopi, tes kulit tusuk pada lengan bawah, dan foto rontgen sefalogram lateral. Cara pengambilan foto sampel dengan menempatkan subjek pada posisi sefalostat dengan mandibula pada oklusi sentrik dan juga bibir pada posisi istirahat. ${ }^{3}$ Jarak antara pasien pada bidang mid sagital dan sumber sinar $\mathrm{x}$ adalah $90 \mathrm{~cm}$, dan sisi lateral kepala subjek menempel pada film negatif. Pengukuran parameter linier dan sudut dilakukan di atas plastik transparan dengan menggunakan spidol tracing untuk analisis sefalometri. Analisis sefalometri OMK dibuat dengan cara mengukur panjang parameter linear yang mempunyai efek determinan pada dimensi panjang tuba eustakius (basis kranial anterior, basis kranial posterior, total panjang basis kranial, kedalaman maksila, tinggi wajah anteroinferior) dan lima sudut yang membangun tipologi wajah, sesuai dengan indeks pertumbuhan vertikal wajah (VERT).

\section{Hasil}

Penelitian ini membandingkan 7 subjek dengan OMK (4 orang laki-laki, 3 orang wanita) dengan 7 subjek kontrol (4 orang wanita dan 3 laki-laki) yang diambil secara consecutive sampling.

Terdapat hubungan yang bermakna antara usia dan terjadinya OMK dengan nilai $\mathrm{p}=0,018$ dan tingkat pendidikan dengan terjadinya OMK $(\mathrm{p}=0,014$; Tabel 1). Jenis kelamin, suku, paparan terhadap polusi asap rokok, dan lingkungan dengan kepadatan tinggi tidak memiliki hubungan dengan kejadian OMK. Usia dan juga tingkat pendidikan dapat merupakan variabel perancu dalam penelitian ini. Jenis kelamin, suku, paparan terhadap asap rokok, dan tinggal di lingkungan yang padat terdistribusi secara homogen pada kedua kelompok, sehingga dapat dijadikan bahan penelitian di masa mendatang.

Tipe OMK terbanyak yaitu 6 dari 7 subjek 


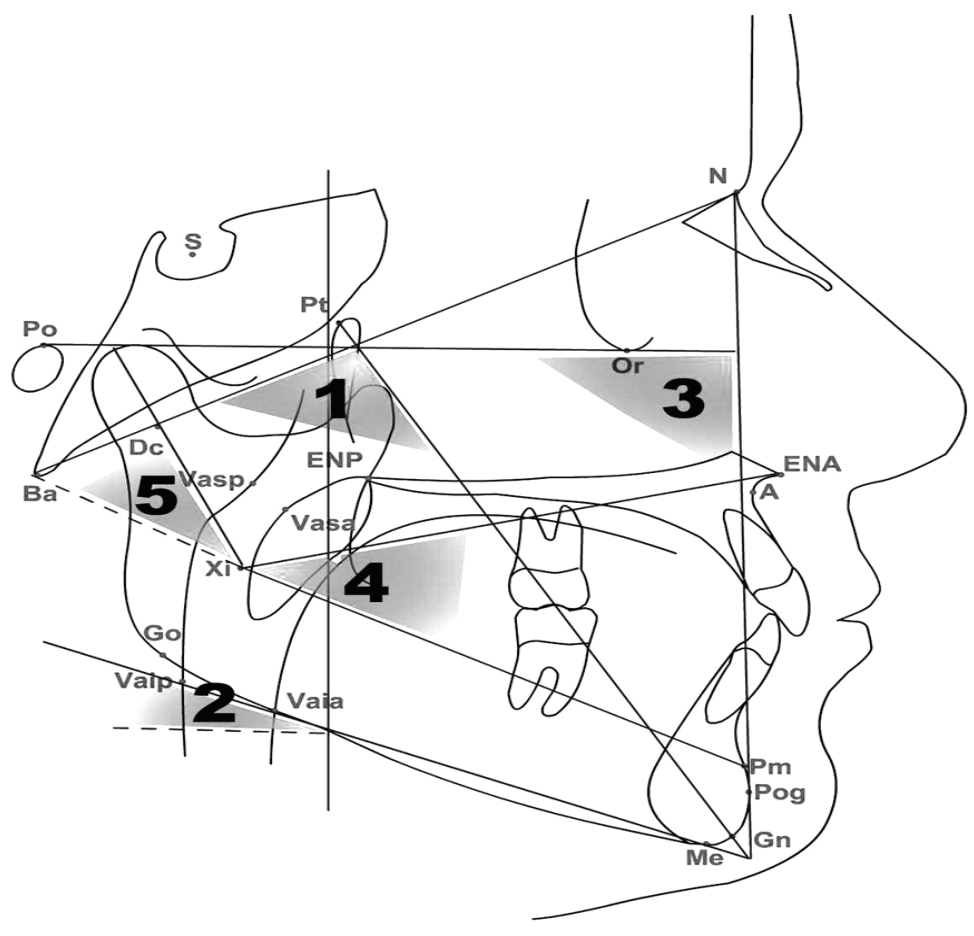

Gambar 1 Analisis Sefalometri oleh Rickets

Sumber: Cde dkk. ${ }^{3}$

\section{Keterangan:}

Titik referensial pada wajah:

$\mathrm{S}=$ Sella:titik tengah dari sela tursika; $\mathrm{Ba}=$ basion: titik tengah batas paling anterior foramen magnum

$\mathrm{N}=$ Nasion: titik paling anterior pada sutura fronto-nasal; $\mathrm{Pt}=$ pterigomaksilaris

Or=Orbital: titik terendah dari bagian anterior pada dinding orbita

Po=Porion: titik tertinggi pada tulang meatus auditorius eksternus

$\mathrm{ENA}=$ spina nasal anterior; $\mathrm{ENP}=$ spina nasal posterior

$\mathrm{Dc}=$ pusat kondilus mandibula; $\mathrm{Xi}=$ pusat mandibula

$\mathrm{Go}=$ Gonion: titik paling posterior dari bagian terendah sudut mandibular.

$\mathrm{M}=$ Menton: titik terendah dari simfisis mandibular; $\mathrm{PM}=$ protuberance mentonian

$\mathrm{GN}=$ Gnathion: titik tengah antara menton dan pogonium pada dagu ditentukan dari bidang midsagital

dagu; VAIA: saluran napas anteroinferior; VASP:saluran napas posterosuperior

VAIP: saluran napas posteroinferior; - $\mathrm{POG}=$ Pogonion: titik paling anterior dagu

\section{Parameter Linier Kraniofasial:}

1.Panjang (S-N): panjang basis kranial anterior; 2.Panjang (S-Ba): panjang basis kranial posterior; 3.Panjang $(\mathrm{Ba}-\mathrm{N})$ : total panjang basis kranial; Garis Frankfort: panjang Po; Or: Ekuivalen dengan posisi horizontal ketika pasien berdiri tegak; 4. Kedalaman maksila: panjang ENA-ENP; 5. Tinggi wajah posterior bagian atas: panjang S-ENP

\section{Parameter sudut kraniofasial:}

1. Aksis wajah: (Ba-N)-(S-Pt-Gn); 2. Mandibular plane: (Po-Or) - (Go-Me); 3. Kedalaman wajah: (Po-Or)(N-Pog); 4. Tinggi wajah anteroinferior: (Xi-ENA)-(Xi-Pm); 5. Arkus mandibular: (Xi-Pm)-(Xi-Dc)

penelitian merupakan tipe maligna yang ditandai dengan keluarnya sekret mukus atau mukopurulen yang berbau busuk disertai kolesteatom baik pada foto Schuller Stenver atau yang didapatkan saat operasi mastoidektomi radikal (Tabel 2).

Tabel 3 memperlihatkan bahwa tidak terdapat perbedaan pada 5 (lima) parameter linier kedua kelompok, dengan $\mathrm{p}>0,005$, tetapi terdapat dua parameter sudut yang berbeda secara bermakna dengan kontrol yaitu sudut mandibular plane dan sudut kedalaman wajah dengan nilai $\mathrm{p}$ masingmasing 0,002 dan 0,005. Nilai indeks VERT berbeda secara bermakna antara kedua kelompok penelitian $(\mathrm{p}=0,041)$ dengan indeks VERT ratarata pada kelompok kasus memperlihatkan pola pertumbuhan wajah brakifasial $(>+0,5)$. 
Henny Widyastuti: Hubungan antara Nilai Indeks Pertumbuhan Vertikal Wajah dan Kejadian Otitis Media Kronik

Tabel 1 Karakteristik Subjek Penelitian

\begin{tabular}{|c|c|c|c|c|}
\hline \multirow{2}{*}{ Karakteristik Subjek } & Kelompok Kasus & Kelompok Kontrol & \multirow{2}{*}{ Total } & \multirow{2}{*}{$\mathbf{p}$} \\
\hline & $\mathbf{n}$ & $\mathbf{n}$ & & \\
\hline \multicolumn{5}{|l|}{ Jenis kelamin } \\
\hline Laki-laki & 4 & 3 & 7 & \multirow[t]{2}{*}{1,0 * } \\
\hline Perempuan & 3 & 4 & 7 & \\
\hline \multicolumn{5}{|l|}{ Usia (tahun) } \\
\hline $20-29$ & 3 & 1 & 4 & \multirow{3}{*}{0,018} \\
\hline $30-39$ & 4 & 1 & 5 & \\
\hline $40-49$ & 0 & 5 & 5 & \\
\hline \multicolumn{5}{|l|}{ Tingkat pendidikan } \\
\hline SD & 2 & 0 & 2 & \multirow{5}{*}{0,014} \\
\hline SMP & 4 & 0 & 4 & \\
\hline SMA & 0 & 2 & 2 & \\
\hline D-1/D-2/D-3 & 0 & 3 & 3 & \\
\hline S1 & 1 & 2 & 3 & \\
\hline \multicolumn{5}{|l|}{ Suku } \\
\hline Sunda & 7 & 5 & 12 & \multirow{3}{*}{$0,475^{\prime}$} \\
\hline Jawa & 0 & 1 & 1 & \\
\hline Palembang & 0 & 1 & 1 & \\
\hline $\begin{array}{l}\text { Paparan terhadap polusi } \\
\text { asap rokok }\end{array}$ & 4 & 4 & 8 & 1,0 \\
\hline $\begin{array}{l}\text { Tinggal di lingkungan } \\
\text { padat penduduk }\end{array}$ & 4 & 1 & 5 & 0,266 \\
\hline
\end{tabular}

Keterangan: *dengan Uji Exact Fischer

Tabel 2 Tipe, Lokasi, dan Komplikasi OMK

\begin{tabular}{lcc}
\hline & \multicolumn{2}{c}{ Tipe OMK } \\
\cline { 2 - 3 } & $\begin{array}{c}\text { OMK } \\
\text { Tanpa Kolesteatom }\end{array}$ & $\begin{array}{c}\text { OMK } \\
\text { Dengan Kolesteatom }\end{array}$ \\
\hline Jenis kelamin: & 0 & 4 \\
$\quad$ Laki-laki & 1 & 2 \\
$\quad$ Wanita & & \\
Komplikasi & 0 & 1 \\
Intratemporal & 0 & 1 \\
Fistel retroaurikular & 0 & 1 \\
$\quad$ Paresis nervus fasialis perifer & & 1 \\
$\quad$ Jaringan granulasi ad regio kanalis akustikus & 0 & 4 \\
$\quad$ Jarternus & 0 & \\
$\quad$ Jotingan granulasi retroaurikular & & \\
\hline
\end{tabular}


Henny Widyastuti: Hubungan antara Nilai Indeks Pertumbuhan Vertikal Wajah dan Kejadian Otitis Media Kronik

Tabel 3 Hubungan Parameter Kraniofasial dengan OMK

\begin{tabular}{|c|c|c|c|c|}
\hline Parameter Kraniofasial & $\begin{array}{c}\text { Kasus } \\
n=7 \\
(m e a n \pm \mathrm{SD})\end{array}$ & $\begin{array}{c}\text { Kontrol } \\
\mathrm{n}=7 \\
(\text { mean } \pm \text { SD })\end{array}$ & $\mathbf{t}$ & $\mathbf{p}$ \\
\hline \multicolumn{5}{|l|}{ Parameter linier (mm): } \\
\hline Basis kranial anterior & $68,86 \pm 9,92$ & $65 \pm 3,42$ & $19,5^{*}$ & \\
\hline Rentang & $61-90$ & $62-72$ & & \\
\hline Basis kranial posterior & $43,57 \pm 6,95$ & $39,57 \pm 2,57$ & 1,43 & 0,18 \\
\hline Rentang & $34-57$ & $36-43$ & & \\
\hline Total panjang basis kranial & $101,86 \pm 9,12$ & $95,29 \pm 5,35$ & 1,65 & 0,13 \\
\hline Rentang & $90-115$ & $90-106$ & & \\
\hline Kedalaman maksila & $47 \pm 7,85$ & $44,14 \pm 1,86$ & 0,94 & 0,37 \\
\hline Rentang & $37-60$ & $42-47$ & & \\
\hline Tinggi wajah posterior & $50,14 \pm 4,45$ & $50,86 \pm 2,19$ & $-0,38$ & 0,71 \\
\hline Rentang & $45-56$ & $48-54$ & & \\
\hline \multicolumn{5}{|l|}{ Parameter sudut $\left({ }^{\circ}\right)$ : } \\
\hline Aksis wajah & $90,29 \pm 5,85$ & $91,57 \pm 1,9$ & $-0,55$ & 0,59 \\
\hline Rentang & $80-97$ & $88-94$ & & \\
\hline Sudut bidang mandibula & $21,29 \pm 4,27$ & $32,43 \pm 5,88$ & $-4,06$ & 0,002 \\
\hline Rentang & $15-26$ & $25-41$ & & \\
\hline Kedalaman wajah & $96,57 \pm 9,16$ & $84,14 \pm 3,02$ & 3,408 & 0,005 \\
\hline Rentang & $85-114$ & $81-90$ & & \\
\hline Tinggi wajah anteroinferior & $49,71 \pm 6,99$ & $50,86 \pm 4,74$ & $-0,36$ & 0,73 \\
\hline Rentang & $40-62$ & $42-57$ & & \\
\hline Arkus mandibula & $32,86 \pm 6,47$ & $32,29 \pm 6,21$ & $-1,01$ & 0,33 \\
\hline Rentang & $26-46$ & $30-48$ & & \\
\hline Indeks VERT & $+0,67 \pm 1,0$ & $-0,42 \pm 0,77$ & 2,286 & 0,041 \\
\hline
\end{tabular}

Keterangan: *Uji Mann-Whitney

Tabel 4 memperlihatkan analisis studi kasuskontrol dengan menggunakan rasio odds, yang menggambarkan frekuensi pajanan OMK itu terhadap kelompok kasus dengan faktor risiko nilai indeks VERT $>+0,5$. Subjek dengan VERT $>+0,5$ (brakifasial) mempunyai risiko 8 kali lebih besar untuk menjadi OMK daripada subjek dengan nilai indeks VERT $<+0,5$ (nonbrakifasial).

\section{Pembahasan}

Prevalensi OMK dipengaruhi oleh usia, status sosial ekonomi, lingkungan padat, dan paparan terhadap asap rokok. Data karakteristik subjek menunjukkan hubungan usia dan juga tingkat pendidikan dengan terjadinya OMK, hal ini sesuai dengan hasil penelitian yang dilakukan oleh

Tabel 4 Odds Ratio Indeks VERT

\begin{tabular}{cccc}
\hline Faktor Risiko & \multicolumn{3}{c}{ Efek } \\
\cline { 2 - 4 } & $\begin{array}{c}\text { Kasus } \\
\text { n }\end{array}$ & $\begin{array}{c}\text { Kontrol } \\
\mathbf{n}\end{array}$ & $\begin{array}{c}\text { Odds Ratio } \\
\text { (IK 95\%) }\end{array}$ \\
\hline VERT $>+0,5$ & 4 & 1 & \\
VERT $<+0,5$ & 3 & 6 & $8(0,41-309,1)^{*}$ \\
Jumlah & 7 & 7 & \\
\hline
\end{tabular}

Keterangan: *dengan nilai median VERT pada grup kasus dan kontrol masing-masing $+0,764 ;-0,518 ; \mathrm{pEF}=0,13$ 
Adoga dkk. ${ }^{1}$ Subjek kasus terbanyak 4/7 subjek berada pada kelompok usia 31-39 tahun terkait dengan tingginya frekuensi berenang dan juga kebiasaan mandi serta berenang tanpa penutup telinga. Kontaminasi air yang masuk dan tertahan di telinga tengah melalui membran timpani yang perforasi akan menyebabkan proses infeksi kronik pada mukosa telinga tengah. ${ }^{10}$ Tingkat pendidikan terbanyak kelompok kasus 4/7 subjek adalah sekolah menengah pertama, sedangkan kontrol 3/7 subjek adalah diploma 1-diploma 3. Paparan terhadap polusi asap rokok, perbedaan jenis kelamin, lingkungan yang padat penduduk, serta suku tidak terbukti berhubungan dengan kejadian OMK, hal ini mungkin disebabkan karena jumlah sampel yang sedikit pada penelitian ini, sebab pada studi yang dilakukan Murphy ${ }^{11}$ dilaporkan bahwa paparan asap rokok terbukti menurunkan mucociliary clearance yang dapat memudahkan adhesi bakteri pada epitel respiratorik sehingga berpotensi memfasilitasi kolonisasi bakteri patogen otitis media. Perbedaan jenis kelamin tidak memiliki hubungan dengan kejadian OMK pada penelitian ini, sesuai dengan studi yang dilaporkan oleh Osazuwa dkk., ${ }^{12}$ perbedaan jenis kelamin tidak berhubungan dengan distribusi bakteri patogen otitis media. Otitis media kronik lebih sering terdapat pada lingkungan yang padat dilaporkan pada studi Shrestha dkk., ${ }^{10}$ sedangkan pada penelitian ini tidak terbukti, mungkin karena jumlah sampel sedikit. Lingkungan yang padat terkait dengan kondisi status sosial ekonomi yang rendah sehingga memudahkan penularan infeksi saluran napas atas dan terjadinya otitis media akut rekuren yang berkembang menjadi OMK.

Studi yang dilakukan peneliti di negara barat melaporkan keterkaitan anatomi bentuk wajah orang-orang eskimo dengan paparan OMK, ${ }^{6}$ pada penelitian ini tidak terbukti keterkaitan antara etnik ras Deutero Melayu dengan kejadian OMK, mungkin karena jumlah sampel sedikit.

Tipe OMK yang terbanyak pada penelitian ini adalah tipe maligna 6 dari 7 subjek, hal ini sesuai dengan penelitian yang dilakukan oleh Shrestha dkk..$^{10}$ dengan $87,5 \%$ subjek penelitiannya adalah tipe OMK maligna. Ting ginya OMK maligna pada penelitian ini mungkin terkait dengan morfologi perforasi yang sebagian besar ditemukan tipe subtotal sehingga memudahkan migrasi debris keratin dari kanalis akustikus eksternus ke rongga telinga tengah. Jenis kelamin laki-laki terbanyak menderita OMK maligna berhubungan dengan frekuensi berenang yang lebih tinggi pada lakilaki bila dibandingkan dengan wanita. Tidak ditemukan komplikasi pada OMK tipe benigna mungkin oleh karena tidak ada kolesteatom yang bersifat destruktif terhadap mukosa, saraf fasialis, dan tulang. Studi yang dilakukan oleh Olszewska dkk. ${ }^{13}$ melaporkan kolesteatom melepaskan $N$ acetyl- $\beta$-D-hexosa minidase (HEX) catalyze yang menyebabkan resorbsi tulang pada ossikula (stapes, incus, maleus) dan tulang-tulang temporal dan menginduksi inflamasi kronik serta jaringan granulasi.

Tidak terdapat perbedaan bermakna parameter linear yang menentukan dimensi panjang dan inklinasi tuba eustakius (Tabel 3), berbeda dengan penelitian yang dilakukan oleh Di Francesco dkk. ${ }^{2}$ dan Kemaloglu ${ }^{2,3}$ yang melaporkan parameter linier penderita OMK ditemukan lebih pendek. Basis kranial adalah kunci pertumbuhan dan perkembangan wajah dan morfologi basis kranial memengaruhi berbagaistrukturyang berhubungan dengannya. Berdasarkan atas teori berpasangan basis kranial menentukan ukuran maksila dan mandibula. Basis kranial anterior yang pendek akan menghasilkan fleksura (lengkung) basis kranial yang tegak, kompleks nasomaksilari yang pendek dan retrusi maksila (bergeser ke posterior) serta pergeseran mandibula ke depan sebagai kompensasi, selanjutnya maksila yang kurang berkembang akan menghasilkan tuba eustakius dan otot tensor veli palatini yang pendek dan kaku, yang berdampak pada fungsi pembukaan tuba eustakius. Tidak terdapat perbedaan yang bermakna parameter linier antara kelompok kasus dan kelompok kontrol mungkin disebabkan karena perbedaan usia antara subjek kedua kelompok, usia rata-rata kelompok kasus adalah 29,43 tahun sedangkan usia rata-rata kelompok kontrol adalah 41,14 tahun. Pada periode usia kelompok kasus terjadi pertumbuhan tulang kraniofasial paling aktif, sedangkan pada kontrol pertumbuhan aktif rangka wajah sudah jauh berkurang. Perbedaan usia akan memberikan pengaruh yang signifikan terhadap ukuran, volume, dan kepadatan tulang. ${ }^{8}$

Selain itu, parameter linier yang panjang pada penelitian ini juga disebabkan oleh perbedaan ras subjek yang digunakan, subjek pada penelitian Di Francesco dkk. ${ }^{2}$ berasal dari Brazilia (campuran ras Kaukasoid dan Negroid) yang sebagian besar tipe wajahnya adalah dolikofasial (bentuk wajah sempit, panjang), sedangkan tipikal wajah subras Deutero Melayu adalah brakifasial. Panjang parameter linier kelompok kasus yang besar dibandingkan dengan kelompok kontrol mungkin menjelaskan meskipun terdapat kesamaan tipikal wajah brakifasial suku Eskimo dan Indian dengan subras Deutero Melayu, tetapi subras Deutero Melayu memiliki parameter linier lebih panjang sehingga mungkin merupakan faktor protektif terhadap insidensi OMK, yang menyebabkan prevalensi OMK subras Deutero Melayu tidak terlalu besar.

Ada 2 (dua) parameter sudut yang berbeda secara bermakna yaitu sudut mandibular plane 
dan kedalaman wajah, keadaan ini sesuai dengan penelitian sebelumnya bahwa penderita otitis media cenderung mempunyai sudut kedalaman wajah yang besar dan sudut mandibular plane yang kecil. ${ }^{2,3}$ Sudut mandibular plane yang kecil pada kelompok kasus terjadi oleh karena subjek memiliki tipe wajah brakifasial (bulat, pendek) dengan bentuk mandibulanya yang pendek dan melebar. ${ }^{8}$ Mandibula tipe brakifasial akan mengalami rotasi kondilus mandibulanya ke anterior ${ }^{8}$ yang akan menghasilkan pertumbuhan wajah ke arah horizontal dengan maksila yang kurang berkembang. Keadaan ini menghasilkan pertumbuhan panjang pars cartilaginous tuba eustakius dan juga otot tensor veli palatini yang pendek $\mathrm{kaku}^{2,3,8}$ yang akan mengganggu fungsi pembukaan tuba dan rentan untuk menjadi OMK.

Sudut kedalaman wajah yang besar pada kelompok kasus menunjukkan disproporsi antara maksila dan mandibula ${ }^{3}$ oleh karena maksila yang kurang berkembang sehingga akan berdampak pada pertumbuhan tuba eustakius dan otot tensor veli palatini yang pendek dan menyebabkan tidak efektifnya pembukaan tuba eustakius sehingga memudahkan terjadinya $\mathrm{OMK} .^{2,3,8}$

Pada penelitian ini, tidak terdapat perbedaan bermakna aksis wajah, tinggi wajah bawah bagian depan, dan arkus mandibula kelompok kasus dengan kelompok kontrol, hal ini berbeda dengan penelitian yang dilakukan oleh Di Francesco dkk. ${ }^{2}$ dan Nery dkk., ${ }^{3}$ yang melaporkan aksis wajah kelompok OMK lebih besar dan tinggi wajah depan bagian bawah yang lebih kecil pada kelompok OMK. Tidak terdapat perbedaan yang bermakna tingginya wajah bawah bagian depan antara kedua kelompok pada penelitian ini, mungkin karena dimensi vertikal tinggi wajah ditentukan oleh banyak faktor (multifaktorial), antara lain arah pertumbuhan kondilar mandibula, dan pertumbuhan vertikal dentoalveolar, serta kekuatan otot mastikator yang ditentukan oleh pola diet subjek. ${ }^{14}$ Pola diet juga mempunyai hubungan erat dengan perkembangan otot-otot mastikatori, pertumbuhan dentoalveolar, serta perkembangan maksila. ${ }^{14}$ Penelitian yang telah dilakukan oleh Tircoveluridkk. ${ }^{14}$ yang melaporkan bahwa ketebalan otot maseter dipengaruhi oleh konsistensi makanan yang telah dikonsumsi. Diet lunak akan menurunkan aktivitas otot maseter yang mengakibatkan menurunnya pertumbuhan dimensi transversal wajah dan meningkatkan pertumbuhan dimensi vertikal wajah.

Pada penelitian ini tidak didapatkan perbedaan yang bermakna antara sudut arkus mandibula subjek kasus dan kontrol, serta ditemukan sudut ini lebih besar daripada nilai normal pada kedua kelompok, hal ini sesuai dengan penelitian yang dilakukan oleh Cde dkk. ${ }^{3}$ Sudut arkus mandibula yang besar menunjukkan arah perkembangan wajah horizontal (tipe wajah brakifasial) dan menunjukkan peran genetik pada etnik subras Deutero Melayu yang cenderung mempunyai mandibula yang pendek dan lebar atau pernah terjadi perkawinan campuran subras Deutero Melayu dengan Proto Melayu atau perkawinan subras Deutero Melayu dan ras asli Indonesia Australomelanosid pada nenek moyang subjek. Ras Proto Melayu maupun ras Australomelanosid memiliki tipikal mandibula yang besar dan lebar.

Nilai indeks (VERT) rata-rata kelompok kasus adalah tipe brakifasial dan berbeda secara bermakna dengan kelompok kontrol dengan nilai $p=0,041$. Indeks VERT $>+0,5$ risiko terhadap terjadinya OMK semakin besar dan Tabel 4. menjelaskan terdapat 8 kali risiko untuk menjadi OMK pada subjek dengan nilai indeks VERT $>+0,5$ nilai interval kepercayaan mencakup nilai 1 mungkin disebabkan karena jumlah subjek penelitian terlalu sedikit.

Simpulan, proporsi bentuk wajah terbanyak penderita OMK subras Deutero Melayu dewasa pada penelitian ini adalah brakifasial (bentuk wajah bulat pendek). Subjek dengan indeks VERT $>+0,5$ (brakifasial) berisiko lebih besar untuk terjadinya OMK, sedangkan pada ukuran parameter linier yang panjang, sudut aksis wajah yang kecil dan tinggi wajah bagian bawah yang besar mungkin berperan sebagai faktor protektif sehingga prevalensi OMK pada subras Deutero Melayu tidak terlalu tinggi dibandingkan dengan suku Aborigin dan Eskimo dan dapat dijadikan penelitian selanjutnya.

\section{Daftar Pustaka}

1. Adoga A, Nimkur T, Silas O. Chronic suppurative otitis media: socio- economic implications in a tertiary hospital in northern Nigeria. Pan Afr Med J. 2010;4(3):1-8

2. Di Francesco RC, Sampaio PL, Bento RF. Correlation between otitis media and craniofacial morphology in adults. Ear Nose Throat J. 2007;86(12):738-43.

3. Cde NG, Buranello FS, Pereira C, Di Francesco RC. Is facial a predisposing factor for otitis media with effusion in children?. Braz J Otorhinolaryngol. 2011; 77(1):84-7.

4. Bernard Ars. Chronic otitis media: pathogenesis oriented therapeutic management. Amsterdam, Netherlands: Kugler Publications; 2008.

5. Naranjilla MA, Janson IR. Cephalometric features of Filipinos with angle class I occlusion according to the Munich analysis. 
Int J Orthod Dentofac: Angle Orthod. 2005; 75(1):63-8.

6. Tikaram A, Chew YK, Zulkiflee AB, Chong AW, Prepageran N. Prevalence and risk factors associated with otitis media with effusion in children visiting tertiary care centre in Malaysia. Int Med J Malaysia. 2012;11(1):37-40.

7. Ridgway EB, Weiner HL. Skull Deformities. Pediatr Clin N Am. 2004;51:359-87.

8. Premkumar S. Craniofacial growth. New Delhi: Jaypee Brothers Medical Publishers; 2011.

9. Cristiany, Budiyanti AE, Hidayat A, Koesoemahardja HD. Differences of lateral cephalometry values between AustraloMelanesian and Deutero-Malay races. J Dent Indonesia. 2013;20(1):9-14.
10. Shrestha BL, Shrestha I, Amatya RC. Comparison of clinical presentation between chronic otitis media mucosal with squamous. Kathmandu Univ Med J. 2010; 8(32):387-91.

11. Murphy TF. Otitis media, bacterial colonization, and the smoking parent. Clin Infect Dis. 2006;42:897-903.

12. Osazuwa F, Nwofor Q, Ibeh IN. Aetiologic agents of otitis media in Benin city, Nigeria. Res J Med Sci. 2011;5(2):112-5.

13. Olszweska E, Olszweska S, Kluczyk MB, Zwierz K. Role of N-acetyl- $\beta$ D-hexosaminidase in cholesteatoma tissue. Acta Biochim Polon. 2007;54(2):365-70.

14. Tircoveluri S, Singh JR, Challa P. Correlation of masseter muscle thickness and intermolar width-an ultrasonography study. J Int Oral Health. 2013;5(2):28-34. 